Research Article

\title{
Cytogenetic analysis of Astylus antis (Perty, 1830) (Coleoptera, Melyridae): Karyotype, heterochromatin and location of ribosomal genes
}

\author{
Ernani de Oliveira Mendes-Neto ${ }^{1}$, Marcelo Ricardo Vicari ${ }^{2}$, Carlos Campaner ${ }^{3}$, Viviane Nogaroto ${ }^{2}$, \\ Roberto Ferreira Artoni ${ }^{2}$ and Mara Cristina Almeida ${ }^{2}$ \\ ${ }^{1}$ Departamento Genética e Evolução, Universidade Federal de São Carlos, São Carlos, SP, Brazil. \\ ${ }^{2}$ Departamento Biologia Estrutural, Molecular e Genética, Universidade Estadual de Ponta Grossa, \\ Ponta Grossa, PR, Brazil. \\ ${ }^{3}$ Museu de Zoologia, Universidade de São Paulo, São Paulo, SP, Brazil.
}

\begin{abstract}
Cytogenetic analysis of Astylus antis using mitotic and meiotic cells was performed to characterize the haploid and diploid numbers, sex determination system, chromosome morphology, constitutive heterochromatin distribution pattern and chromosomes carrying nucleolus organizer regions (NORs). Analysis of spermatogonial metaphase cells revealed the diploid number $2 \mathrm{n}=18$, with mostly metacentric chromosomes. Metaphase I cells exhibited $2 n=8 I I+X y p$ and a parachute configuration of the sex chromosomes. Spermatogonial metaphase cells submitted to C-banding showed the presence of small dots of constitutive heterochromatin in the centromeric regions of nearly all the autosomes and on the short arm of the X chromosome (Xp), as well as an additional band on one of the arms of pair 1. Mitotic cells submitted to double staining with base-specific fluorochromes $\left(\mathrm{DAPI}-\mathrm{CMA}_{3}\right)$ revealed no regions rich in $\mathrm{A}+\mathrm{T}$ or $\mathrm{G}+\mathrm{C}$ sequences. Analysis of spermatogonial mitotic cells after sequential Giemsa/ $\mathrm{AgNO}_{3}$ staining did not reveal any specific mark on the chromosomes. Meiotic metaphase I cells stained with silver nitrate revealed a strong impregnation associated to the sex chromosomes, and in situ hybridization with an 18S rDNA probe showed ribosomal cistrons in an autosomal bivalent.
\end{abstract}

Key words: sex chromosomes, meiosis, metaphase, FISH, 18S rDNA.

Received: July 30, 2009; Accepted: November 17, 2009.

\section{Introduction}

The suborder Polyphaga is the most numerous of the order Coleoptera and displays the greatest structural and biological diversity of species (Gillot, 1995; Costa, 1999). The superfamily Cleroidea belongs to the suborder Polyphaga and comprises approximately 10,000 taxonomically described species (Costa, 2003), distributed among eight families (Lawrence and Newton, 1995), such as Melyridae, with approximately 5000 species, 68 of which occur in the Neotropical region (Costa, 2003). The genus Astylus belongs to the family Melyridae and includes a number of Brazilian species, such as Astylus antis, A. quadrilineatus, A. sexmaculatus and $A$. variegatus, which are best known for visiting the flowers of cultivated plants, such as corn, cotton and sorghum (Rosseto and Rosseto, 1976; Souza and Carvalho, 1994; Ventura et al., 2007).

Send correspondence to Mara C. Almeida. Laboratório de Citogenética e Evolução, Departamento de Biologia Estrutural Molecular e Genética, Universidade Estadual de Ponta Grossa, Av. Carlos Cavalcanti 4748, 84030-900 Ponta Grossa, PR, Brazil. E-mail: almeidamara@uol.com.br.
In the superfamily Cleroidea, only 16 species have been cytogenetically analyzed, 12 species belonging to the family Cleridae and four species of the family Melyridae. The 12 species of Cleridae, distributed among five genera (Enoclerus, Priocera, Thanasimus, Trichodes and Necrobia), exhibit karyotype uniformity, i.e., $2 \mathrm{n}=18$, the basal sex determination system for Coleoptera, Xyp, and meta/submetacentric morphology for all chromosomes (Smith, 1953; Virkki, 1963; Smith and Virkki, 1978; Yadav and Dange, 1989; Schneider et al., 2007a). However, the four species belonging to the family Melyridae display differences both in their chromosome number and their sex determination system (Smith and Virkki, 1978). Chromosome morphology was only described for $A$. variegates, in which all chromosomes are metacentric (Schneider et al., 2007a).

Cytogenetic data using differential staining in species of Cleroidea are limited to A. variegatus, which has small blocks of heterochromatin in the pericentromeric region of all chromosomes, except Xyp. In this species, the nucleolus organizer region (NOR) is located in autosome pair 2 (Schneider et al., 2007a). 
In Coleoptera with the Xyp sex determination system, it is common to find nucleolus material associated to the sex chromosomes. Furthermore, there are a number of different mechanisms described to explain the association and segregation of these chromosomes in meiosis, depending on their degree of differentiation. These mechanisms oscillate between a nucleolus association and/or a synaptic association (Smith and Virkki, 1978; Juan et al., 1993; Petitpierre, 1996). In Coleoptera, however, NORs are located in either autosomes and/or sex chromosomes (Almeida et al., 2000; Schneider et al., 2007a, 2007b). The few studies that have employed fluorescent in situ hybridization (FISH) in Coleoptera have found conflicting results between the location of the rDNA genes and the silver staining, particularly regarding the sex chromosomes of the Xyp system in some species. Therefore, the nucleolus theory for the maintenance and segregation of the sex chromosomes belonging to this system (Weber, 1971; Drets et al., 1983; Virkki, 1983; Postiglioni and Brum-Zorilla, 1988; Postiglioni et al., 1991; Juan et al., 1993; Maffei et al., 2001) has been questioned (Juan et al., 1993; Moura et al., 2003; Schneider et al., 2007a, 2007b).

In order to understand how chromosome evolution occurred in the different species of this group, it is important to establish the constitutive heterochromatin distribution pattern and to identify the NOR-bearing chromosomes. These were the aims of the present study, in addition to chromosomally characterize the species Astylus antis, using both the mitotic karyotype and meiotic cells.

\section{Materials and Methods}

The 17 specimens of Astylus antis (Perty, 1830) analyzed were collected in the cities of Carambeí (S 24'58'071'; W 50'06'817') and Ponta Grossa (S 2508'985"; W 49 58'992') in the region of Campos Gerais, Paraná, Brazil.

Cytological preparations were obtained from the gonads of adult male individuals. The gonads were removed in insect saline solution, treated with hypotonic solution (tap water) for six minutes and fixed in Carnoy I. Then, the gonads were macerated in $45 \%$ acetic acid solution, and the slides were dried on a metal plate at a temperature of 35 to $40{ }^{\circ} \mathrm{C}$; later on, the slides were stained with $3 \%$ Giemsa in pH 6.8 phosphate buffer for $15 \mathrm{~min}$.

The C-banding and base-specific fluorochrome staining (DAPI/CMA ${ }_{3}$ ) methods described by Sumner (1972) and Schweizer (1980), respectively, were used to determine the distribution and the AT/GC content of the constitutive heterochromatin. The silver nitrate impregnation method described by Howell and Black (1980) and the fluorescent in situ hybridization (FISH) method with $18 \mathrm{~S}$ rDNA described by Pinkel et al. (1986) were used to identify the chromosomes bearing NORs. The partial 18S rDNA probe
(732 pb) was obtained through amplification by PCR labeled with biotin-14-dATP hapten (Invitrogen), using the cloned 18S fragment of Omophoita octoguttata (Coleoptera) as template. The hybridization signals were detected using avidin-fluorescein isothiocyanate (Avidin-FITC, Sigma). For amplification of the signals, we used anti-avidin biotinylated (Sigma) and Avidin-FITC (Sigma) conjugated antibodies. Overall hybridization was performed under high stringency conditions $(2.5 \mathrm{ng} / \mu \mathrm{L}$ probes, $50 \%$ deionized formamide, $10 \%$ dextran sulfate, 2XSSC at $37{ }^{\circ} \mathrm{C}$ overnight). After hybridization, the slides were washed in $15 \%$ formamide/0.2XSSC at $42{ }^{\circ} \mathrm{C}$ for $20 \mathrm{~min}, 0.1 \mathrm{XSSC}$ at $60{ }^{\circ} \mathrm{C}$ for $15 \mathrm{~min}$, and $4 \mathrm{XSSC} / 0.05 \%$ Tween at room temperature for $10 \mathrm{~min}$, the latter consisting of two washes of $5 \mathrm{~min}$ each. Chromosomes were counterstained with DAPI $(0.2 \mathrm{mg} / \mathrm{mL})$ in anti-fade solution.

Approximately 40 cells from each specimen were examined. Chromosomes were counted and identified whenever possible. The best mitotic and meiotic cells in both conventional and differential staining were photographed under an optical photomicroscope (Olympus BX41), with a 100x immersion objective. The metaphase cells submitted to the base-specific fluorochromes and FISH were photographed with a digital camera (Olympus C-5060 5.1 Megapixel) with specific filters, or recorded by real-time digital imaging with a DP-71 camera and DP controller software.

The karyotypes were arranged and numbered in decreasing order, based on size and morphology of the chromosomes, and the homologous chromosomes were tentatively paired to facilitate presentation and comparison, as proposed by Levan et al. (1964).

\section{Results}

\section{Conventional staining}

Analysis of spermatogonial metaphase cells revealed the diploid chromosome complement $2 \mathrm{n}=18=16+$ Xyp. Most of the autosomes were metacentric, only pairs 5 and 7 were submetacentric. The Xp chromosome was submetacentric, and the yp chromosome was extremely small, which made it impossible to determine its morphology but it may be acrocentric (Figure 1a).

The pachytene cells showed all bivalents completely, including the sex chromosomes, which displayed a parachute configuration. Small positive heteropycnotic blocks were found in these cells (Figure 2a). The study of diplotene cells revealed the occurrence of one or two chiasmata per bivalent (Figure 2b). The metaphase I cells examined showed the chromosome meioformula $2 \mathrm{n}=8 \mathrm{II}+\mathrm{Xyp}$ and the parachute configuration of the sex chromosomes (Figure 2c). The metaphase I cells showed a haploid complement $\mathrm{n}=8+\mathrm{Xp}$ or $\mathrm{n}=8+\mathrm{yp}$ (Figures $2 \mathrm{~d}$ and $2 \mathrm{e}$ ), indicating normal chromosome segregation during anaphase I. The yp 
a)
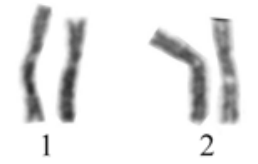

is

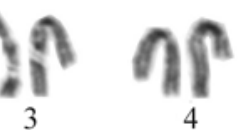

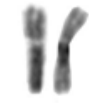

6

b)

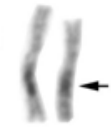

1

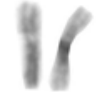

6

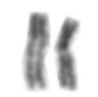

7

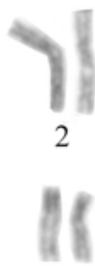

7

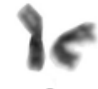

8

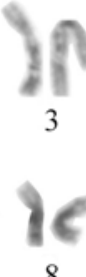

8

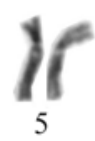

5

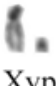

Xур

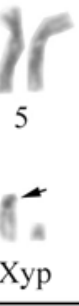

Figure 1 - Mitotic karyotype of a male Astylus antis specimen with $2 \mathrm{n}=18=16+\mathrm{X}+\mathrm{yp}$ : a. chromosomes stained with Giemsa; b. the same cell after $\mathrm{C}$-banding, showing the centromeric heterochromatin region on the $\mathrm{X}$ chromosome (larger arrows) and an additional band on one of the arms of pair 1 (smaller arrow). Bar $=5 \mu \mathrm{m}$.

chromosome exhibited negative heteropycnosis in the majority of meiotic phases analyzed.

\section{Differential staining}

C-banding and base-specific fluorochrome (DAPI/CMA ${ }_{3}$ ) staining of spermatogonial metaphase cells revealed the presence of small dots of heterochromatin in the centromeric regions of most autosomes, as well as an interstitial band on one of the arms of the pair 1 chromosomes and on the short arm of the Xp chromosome (Figure 1b), but with no differentiation between AT- and GC-rich sites (data not shown). Sequential Giemsa/ $\mathrm{AgNO}_{3}$ staining of spermatogonial mitotic cells revealed no NOR-specific labeling on the chromosomes.

Meiotic cells submitted to C-banding and basespecific fluorochrome staining showed no specific AT- or GC-rich blocks or sites. Sequential Giemsa/ $\mathrm{AgNO}_{3}$ staining of meiotic metaphase I cells revealed strong silver nitrate impregnation on the sex chromosomes (Figures $3 \mathrm{a}$ and $3 b)$. This block was interpreted as argyrophilic material. FISH analysis of pachytene and metaphase I cells using an $18 \mathrm{~S}$ rDNA probe revealed a fluorescent signal strongly associated to an autosomal bivalent and no labeling on the sex chromosomes (Figures $3 \mathrm{c}$ and $3 \mathrm{~d}$ ).

\section{Discussion}

The results obtained for Astylus antis regarding the sex determination system, chromosome morphology, C-band distribution pattern and location of NORs are in agreement with those described for many other species of Coleoptera. The $2 \mathrm{n}=18=16+$ Xyp chromosome number is similar to that described for the 12 species of Cleridae (Smith, 1953; Virkki, 1963; Smith and Virkki, 1978; Yadav and Dange, 1989), whereas it is in agreement with only one of the four Melyridae species analyzed - A. variegatus (Schneider et al., 2007a). Furthermore, the chromosome
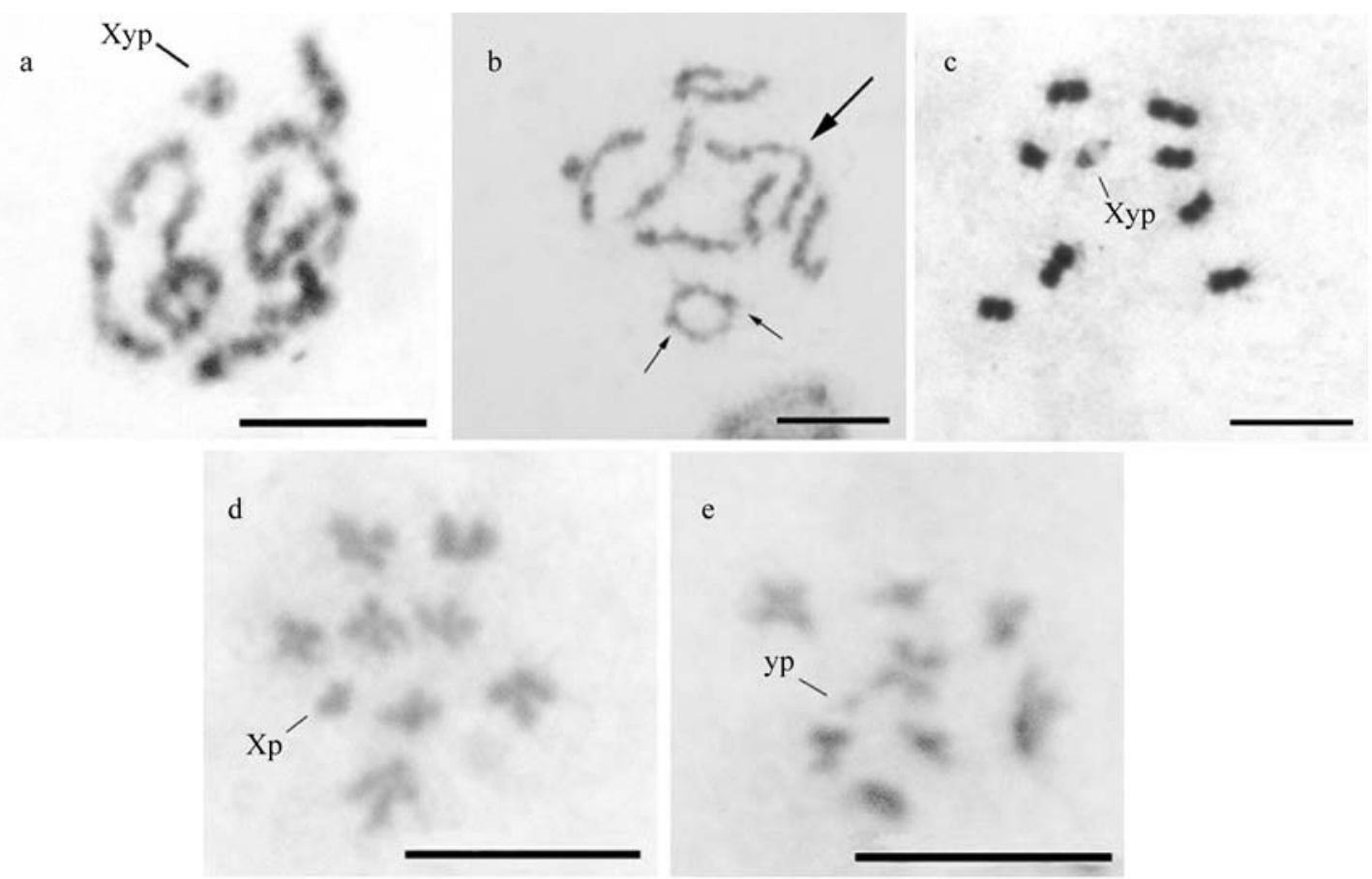

$\mathrm{e}$

Figure 2 - Meiotic cells from Astylus antis: a. pachytene cells; b. diplotene with $2 \mathrm{n}=8 \mathrm{II}+\mathrm{Xyp}$ (arrows = chiasmata); $\mathrm{c}$. metaphase I cell, showing $2 \mathrm{n}=8 \mathrm{II}+\mathrm{Xyp} ; \mathrm{d}$. and e. metaphase II cells, with $\mathrm{n}=8+\mathrm{X}$ and $\mathrm{n}=8+\mathrm{y}$, respectively. Bar $=5 \mu \mathrm{m}$. 
a)
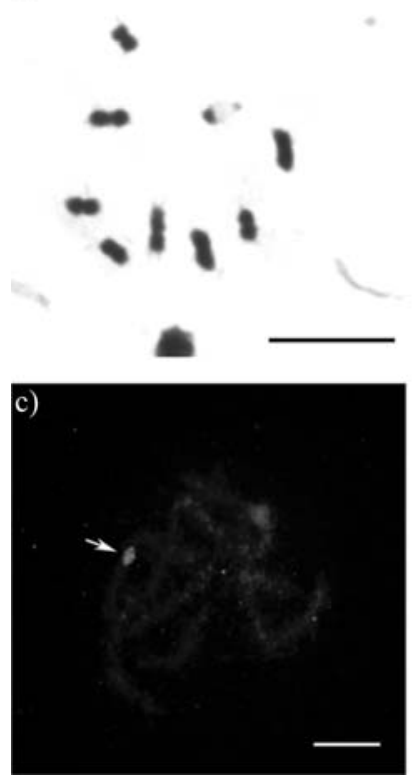

b)
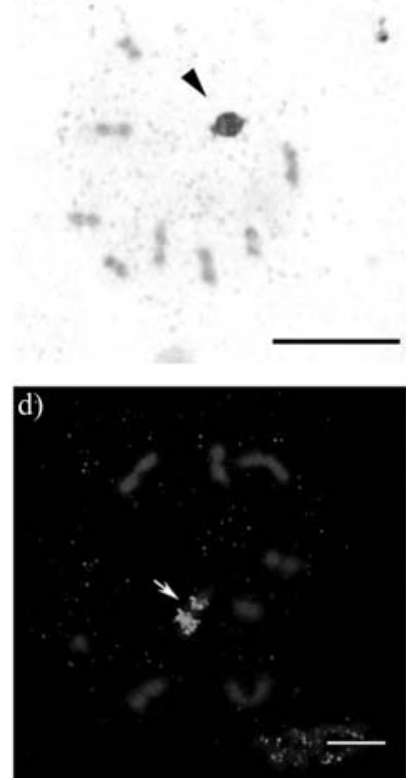

Figure 3 - Meiotic cells from Astylus antis: a. metaphase I cell stained with Giemsa, $2 n=8 I+X y p ; b$. the same cell stained with silver nitrate, showing strong impregnation associated to the sex chromosomes (arrowhead); c. and d. pachytene and metaphase I cells, respectively, hybridized with an 18S rDNA probe, showing an autosomal bivalent with a fluorescent signal (arrows). Bar $=5 \mu \mathrm{m}$.

formula $2 \mathrm{n}=18$ differs from the $2 \mathrm{n}=20=18+$ Xyp described as basal for the order by Smith (1950) and supported by a number of recent studies (Maffei et al., 2000; 2001; Moura et al., 2003; Rozek et al., 2004; Almeida et al., 2000; Schneider et al., 2007a, 2007b). The difference between the chromosome number found and the basal number may be explained by the occurrence of fusion-type chromosome rearrangements between two pairs of autosomes, followed by pericentric inversion, as also proposed for A. variegatus by Schneider et al. (2007a).

According to Smith and Virkki (1978), the evolutionary tendency for Coleoptera of the suborder Polyphaga was to maintain the chromosome number close to the original, whereas, for representatives of Adephaga, the tendency was to increase the chromosome number through autosomal centric fission. However, centric fusion events appear to be less frequent, as there are only few species with low chromosome numbers.

In the few cytogenetically studied species from the family Cleridae, no change in sex chromosomes was observed, so the Xyp sex determination system was maintained. Nevertheless, in the family Melyridae, maintenance of the Xyp system has been observed in Hoppigiana hudsonica $(2 \mathrm{n}=6 \mathrm{II}+\mathrm{Xyp})$ and $A$. variegatus $(2 \mathrm{n}=8 \mathrm{II}+\mathrm{Xyp})$, while Collops sp $(2 \mathrm{n}=8 \mathrm{II}+\mathrm{X} 0)$ and Endeodes collaris $(2 \mathrm{n}=9 \mathrm{II}+\mathrm{X} 0)$ lost the yp chromosome, giving rise to an $\mathrm{X} 0$ sex determination system (Smith,
1953; Virkki, 1963; Smith and Virkki, 1978; Yadav and Dange, 1989; Schneider et al., 2007a).

Small karyotype differences were found when comparing the results from $A$. antis with the description for $A$. variegatus regarding the metacentric morphology of all the chromosomes, the behavior of the sex chromosomes and the presence of B chromosomes (Schneider et al., 2007a). Thus, it can be inferred that small rearrangements of the inversion type and differentiation of the sex chromosomes occurred during the chromosome differentiation of these species.

Negative heteropycnosis as observed in the yp chromosome of $A$. antis has also been found in some species of Coleoptera, including $A$. variegatus. Differences involving heteropycnosis may occur due to differential chromosome condensation and/or the presence of a special type of chromatin (Virkki, 1967; Yadav et al., 1985; Almeida et al., 2000). The number of chiasmata found in A. antis is in agreement with the number described for most species of Coleoptera, as well as for Enoclerus sp, Necrobia ruficollis and Astylus variegatus, which belong to the superfamily Cleroidea (Virkki, 1963; Yadav and Dange, 1989; Schneider et al., 2007a).

The centromeric constitutive heterochromatin pattern observed in $A$. antis by $\mathrm{C}$-banding is in line with that described for various species of Coleoptera, including those with the Xyp sex determination system, such as Epilachna paenulata (Drets et al., 1983), Gonocephalum patruele, G. rusticum, Hegeter grancanariensis, Pachychila sublunata, Tenebrio molitor, Tentyria grossa (Juan and Petitpierre, 1989), Epicauta atomaria, Palembus dermestoides (A1meida et al., 2000), Eriopis connexa (Maffei et al., 2000), Phyllophaga (Phytalus) vestita (Moura et al., 2003), Adelocera murina, Oedemera podagraridae, O. virescens (Rozek et al., 2004), and Astylus variegatus (Schneider et al., 2007a). However, the interstitial band found on the long arm of the chromosomes of pair 1 in Astylus antis is not present in the karyotype of $A$. variegatus.

From the results obtained with the double staining (DAPI/CMA 3 ), which coincide with those obtained by Cbanding, it can be concluded that the weakly fluorescent signals are heterochromatic regions, but with no differentiation between AT- and GC-rich sites. A number of studies have attempted to explain the conflicting results between the content of DNA bases and responses to base-specific fluorochromes (Comings and Drets, 1976; Saitoh and Laemmli, 1994; Vicari et al., 2008). The fluorochrome DAPI binds to DNA, but its fluorescence is significantly enhanced in AT-rich domains. According to Comings and Drets (1976), Comings (1978) and Johnston et al. (1978), the antibiotic daunomycin only emits fluorescence when the AT content exceeds $65 \%$. According to Vicari et al. (2008), the absence of fluorescence on large heterochromatic blocks of the fish Astyanax janeiroensis is due to the 
effect of competition between two families of repetitive DNA co-located in the same chromosome domains. Contrarily, competition and/or excitation energy transference between DAPI and $\mathrm{CMA}_{3}$, together with the absence of AT/GC differentiation in these regions (Zimmer et al., 1971) and the state of heterochromatic compaction, could explain the coinciding results of the $\mathrm{C}$-bands and the DAPI-CMA $_{3}$ fluorochrome signals (Saitoh and Laemmli, 1994).

Moura et al. (2003) obtained similar results using triple $\mathrm{CMA}_{3} / \mathrm{DA} / \mathrm{DAPI}$ staining: they found that in Phyllophaga (Phytalus) vestita there was no difference between the $\mathrm{CMA}_{3}$ and DAPI signals, both of which were positive. Lyogenys fuscus displays a strong fluorescent signal by DAPI in the pericentromeric region of all chromosomes. Likewise, Vitturi et al. (1999) found that positive $\mathrm{CMA}_{3}$ regions coinciding with $\mathrm{C}$ bands were also DAPIpositive in Thorectes intermedius (Geotrupidae).

Analyzing Epilachna paenulata with the fluorochrome method (Quinacrine $\mathrm{HCl}$ or Hoechst 33258), Drets et al. (1983) found intensely fluorescent regions in the centromeric region of the autosomes, a region rich in AT sequences. Juan et al. (1991) studied Tenebrio molitor and Plohl et al. (1993) analyzed testicular cells from Tribolium confusum using DA/DAPI fluorochromes and found that the pericentromeric and centromeric regions of all chromosomes in the complement were rich in AT sequences.

FISH with the $18 \mathrm{~S}$ rDNA probe revealed a fluorescence signal strongly associated to an autosomal bivalent in Astylus antis. The labeling obtained by silver nitrate staining on the sex chromosomes without the presence of ribosomal cistrons (which were detected by FISH only in one autosomal bivalent) in $A$. antis is in agreement with the results obtained for other species of Coleoptera with the Xyp system (Vitturi et al., 1999; Colomba et al., 2000a; Moura et al., 2003; Bione et al., 2005). It is also in agreement with a survey carried out by Schneider et al. (2007b), in which $81 \%$ of Adephaga and Polyphaga species had NORs located on the autosome pairs. The silver staining of these nonspecific blocks may result from the presence of an argyrophilic substance, which theoretically facilitates the configuration, maintenance and segregation of the sex chromosomes of the Xyp system, as described by a number of authors (Virkki et al., 1990, 1991; Juan et al., 1993; Petitpierre, 1996; Moura et al., 2003; Bione et al., 2005; Schneider et al., 2007a, 2007b). A large number of studies have associated these nonspecific silver nitrate marks with argyrophilic proteins and heterochromatic regions, particularly proteins associated to these regions (Virkki et al., 1991; Vitturi et al., 1999; Colomba et al., 2000a, 2000b, 2004, 2006; Bione et al., 2005).

The karyotype differences observed regarding chromosome morphology, C-banding patterns and behavior of the sex chromosomes in meiosis of $A$. antis in comparison to the description of $A$. variegatus suggest that the karyotype evolution of these two species may have involved different types of chromosome rearrangements, such as small inversions and the addition of heterochromatin. Regarding the plesiomorphic characteristics for the order, the reduction in number may have occurred due to pericentric inversion, followed by fusion between autosomes, with no involvement of the sex chromosomes.

\section{Acknowledgments}

The authors are grateful to the Brazilian agencies Fundação Araucária de Apoio ao Desenvolvimento Científico e Tecnológico do Estado do Paraná (Process $N^{o}$ 05155/2008) and Conselho Nacional de Desenvolvimento Científico e Tecnológico - $\mathrm{CNPq}$ (Process $\mathrm{N}^{\mathrm{o}}$ 476878/2007-1) for financing this project. Thanks are also due to Mr. Miguel Airton Carvalho for his collaboration in field and laboratory activities.

\section{References}

Almeida MC, Zacaro AA and Cella DM (2000) Cytogenetic analysis of Epicauta atomaria (Meloidae) and Palembus dermestoides (Tenebrionidae) with Xyp sex determination system using standard staining, C-bands, NOR and synaptonemal complex microspreading techniques. Hereditas 133:147-157.

Bione E, Moura RC, Carvalho R and Souza MJ (2005) Karyotype, $\mathrm{C}$ - and fluorescence banding pattern, NOR location and FISH study of five Scarabaeidae (Coleoptera) species. Genet Mol Biol 28:376-381.

Colomba MS, Vitturi R and Zunino M (2000a) Karyotype analysis, banding, and fluorescent in situ hybridization in the Scarab beetle Gymnopleurus sturni McLeady (Coleoptera, Scarabaeoidea, Scarabaeidae). Heredity 91:260-264.

Colomba MS, Vitturi R and Zunino M (2000b) Chromosome analysis and rDNA FISH in the stag beetle Dorcus parallelipipedus L. (Coleoptera, Scarabaeoidea, Lucanidae). Hereditas 133:249-253.

Colomba M, Vitturi R, Volpe N, Lannino A and Zunino M (2004) Karyotype banding and rDNA FISH in the scarab beetle Anoplotrupes stercorosus (Coleoptera Scarabaeoidea, Geotrupidae). Description and comparative analysis. Micron 35:717-720.

Colomba M, Vitturi R, Libertini A, Gregorini A and Zunino M (2006) Heterochromatin of the scarab beetle, Bubas bison (Coleoptera, Sacarabaiedae) II: Evidence for AT-rich compartmentalization and high amount of rDNA copies. Micron 37:47-51.

Comings DE (1978) Mechanisms of chromosome banding and implications for chromosome structures. Annu Rev Genet 12:25-46.

Comings DE and Drets ME (1976) Mechanisms of chromosome banding. IX. Are variations in DNA base composition adequate to account for Quinacrine, Hoechst 33258 and daunomycin banding? Chromosoma 56:99-211.

Costa C (1999) Coleoptera. In: Joly CA and Bicudo CEM (eds) Biodiversidade do Estado de São Paulo: Uma Síntese do 
Conhecimento ao Final do Século XX. Editora FAPESP, São Paulo, pp 113-122.

Drets ME, Corbella E and Folle GA (1983) C-banding and nonhomologous associations. II. The "parachute" Xyp sex bivalent and the behavior of heterocromatic segments in Epilachna paenulata. Chromosoma 88:249-255.

Gillot C (1995) Entomology. 2nd edition. Plenum Press, New York, $798 \mathrm{pp}$.

Howell WM and Black DA (1980) Controlled silver staining of nucleolus organizer regions with protective colloidal developer: A 1-step method. Experientia 36:1014-1015.

Johnston FP, Jorgenson KF, Lin CC and Sande JH (1978) Interaction of anthracyclines with DNA and chromosomes. Chromosoma 68:15-129.

Juan C and Petitpierre E (1989) C-banding and DNA content in seven species of Tenebrionidae (Coleoptera). Genome 32:834-839.

Juan C, Gosálvez J, Mezzanotte R and Petitpierre E (1991) Cytological and biochemical characterization of the in situ endonuclease digestion of fixed Tenebrio molitor chromosomes. Chromosoma 100:432-438.

Juan C, Pons J and Petitpierre E (1993) Localization of tandemly repeated DNA sequences in beetle chromosomes by fluorescent in situ hybridization. Chromosome Res 1:167-174.

Lawrence JF and Newton AF (1995) Families and subfamilies of Coleoptera (with selected genera, notes, references and data on family-group names). In: Pakaluk J and Slipinski SA (eds) Biology, Phylogeny and Classification of Coleoptera: Papers Celebrating the $80^{\text {th }}$ Birthday of Roy A. Crowson. Muzeum I Institut Zoologii, Warszawa, pp 559-1092.

Levan A, Fredga K and Sandberg AA (1964) Nomenclature for centromeric position on chromosomes. Hereditas 52:201220.

Maffei EMD, Gasparino E and Pompolo SG (2000) Karyotypic characterization by mitosis, meiosis and C-banding of Eriopis connexa Mulsant (Coccinellidae, Coleoptera, Polyphaga), a predator of insect pests. Hereditas 132:79-85.

Maffei EMD, Pompolo SG, Campos LAO and Petitpierre E (2001) Sequential FISH analysis with rDNA genes and AgNOR banding in the lady beetle Olla v-nigrum (Coleoptera, Coccinellidae). Hereditas 135:13-18.

Moura RC, Souza MJ, Mello NF and Lira-Neto AC (2003) Karyotypic characterization of representatives from Melolonthinae (Coleoptera, Scarabaeidae): Karyotypic analysis, banding and fluorescent in situ hybridization (FISH). Hereditas 138:200-206.

Petitpierre E (1996) Molecular cytogenetics and taxonomy of insects, with particular reference to the Coleoptera. Int J Insect Morphol Embryol 25:115-134.

Pinkel D, Straume T and Gray JW (1986) Cytogenetic analysis using quantitative, high-sensitivity, fluorescent hybridization. Proc Natl Acad Sci USA 83:2934-2938.

Plohl M, Lucijanic-Justic V, Ugarkovic D, Petitpierre E and Juan C (1993) Satellite DNA and heterochromatin of the flour beetle Tribolium confusum. Genome 36:467-475.

Postiglioni A and Brum-Zorrilla N (1988) Non-relationship between nucleolus and sex chromosome system XYp in Chelymorpha variabilis Boheman (Coleoptera, Chrysomelidae). Genetica 77:137-141.

Postiglioni A, Stoll M and Brum-Zorrilla N (1991) Haploid karyotype analysis of Chelymorpha variabilis Boheman (Co- leoptera, Chrysomelidae) with microspreading techniques. Rev Bras Genet 14:653-660.

Rosseto CJ and Rosseto D (1976) Astylus variegatus (Germar, 1824) (Coleoptera, Dasytidae) danificando o sorgo. Bragantia 35:131-132.

Rozek M, Lachowska D, Petitpierre E and Holecová M (2004) C-bands on chromosomes of 32 beetle species (Coleoptera, Elateridae, Cantharidae, Oedemeridae, Cerambycidae, Anthicidae, Chrysomelidae, Attelabidae and Curculionidae). Hereditas 140:161-170.

Saitoh Y and Laemmli UK (1994) Metaphase chromosome structure: Bands arise from a differential folding path of the highly AT-rich scaffold. Cell 76:609-622.

Schneider MC, Carraro BP, Cella DM, Matiello RR, Artoni RF and Almeida MC (2007a) Astylus variegatus (Coleoptera, Melyridae): Cytogenetic study of a population exposed to agrochemical products. Genet Mol Biol 30:640-645.

Schneider MC, Rosa SP, Almeida MC, Costa C and Cella DM (2007b) Strategies of karyotype differentiation in Elateridae (Coleoptera, Polyphaga). Micron 38:590-598.

Schweizer D (1980) Simultaneous fluorescent staining of R_Bands and specific heterochomatic regions (DA-DAPI bands) in human chromosomes. Cytogenet Cell Genet 27:90-193.

Smith SG (1950) The cyto-taxonomy of Coleoptera. Can Entomol 82:58-68.

Smith SG (1953) Chromosome numbers of Coleoptera. Heredity 7:31-48.

Smith SG and Virkki N (1978) Animal Cytogenetics. Gebr Borntraeger, Berlin, $366 \mathrm{pp}$.

Souza B and Carvalho CFC (1994) Aspectos morfológicos do adulto de Astylus variegatus (Germar, 1824) (Coleoptera, Mlyridae). Pesqui Agropecu Bras 29:689-694.

Sumner AT (1972) A simple technique for demonstrating centromeric heterochromatin. Exp Cell Res 75:304-306.

Ventura MU, Pereira T, Nunes DH and Arruda IC (2007) Attraction of Astylus variegatus (Germ.) (Coleoptera, Melyridae) by volatile floral attractants. Sci Agric 64:306-307.

Vicari MR, Artoni RF, Moreira-Filho O and Bertollo LAC (2008) Co-localization of repetitive DNAs and silencing of major rDNA genes. A case report in the fish, Astyanax janeiroensis. Cytogenet Genome Res 122:67-72.

Virkki N (1963) On the cytology of some Neotropical Cantharoids (Coleoptera). Ann Acad Sci Fenn A-IVB 65:1-17.

Virkki N (1967) Chromosome relationships in some North American scarabaeoid beetles, with special reference to Pleocoma and Trox. Can J Genet Cytol 9:107-125.

Virkki N (1983) Banding of Oedionychina (Coleoptera, Alticinae) chromosomes: C- and Ag-bands. J Agric Univ Puerto Rico 67:221-255.

Virkki N, Mazzella C and Denton A (1990) Staining of substances adjacent to the sex bivalent in certain weevils of Puerto Rico. J Agric Univ Puerto Rico 74:405-418.

Virkki N, Mazzella C and Denton A (1991) Silver staining of the coleopteran $\mathrm{Xy}_{\mathrm{p}}$ sex bivalent. Cytobios 67:45-63.

Vitturi R, Colomba MS, Barbieri R and Zunino M (1999) Ribosomal DNA location in the scarab beetle Thorectes intermedius (Costa) (Coleoptera, Geotrupidae) using banding and fluorescent in situ hybridization. Chromosome Res $7: 255-260$. 
Weber F (1971) Korrelierte Formveränderungen von Nukleolus und nukleolusassoziiertem Heterochromatin bei der Gattung Carabus (Coleoptera). Chromosoma 34:261-273.

Yadav JS and Dange MP (1989) On the cytology of two species of Necrobia (Oliv.) (Coleoptera, Cleridae). Genome 32:165167.

Yadav JS, Condal K and Yadav AS (1985) Karyotypic notes on 12 species of Carabid beetles (Caraboidea, Adephaga) from Haryana. Zool Anz 215:338-347.

Zimmer CH, Reinert KE, Luck G, Wähnert U, Löber G and Thrum H (1971) Interaction of the oligopeptide antibiotics netropsin and distamycin A with nucleic acids. J Mol Biol 58:329-348

\section{Internet Resources}

Costa C (2003) Estado de conocimiento de los Coleoptera neotropicales. Bol SEA (Versión Eletronica 32). http://www.sea-entomologia.org/aracnet/11/01/index.htm (April 23, 2010).

Associate Editor: Yatiyo Yonenaga-Yassuda

License information: This is an open-access article distributed under the terms of the Creative Commons Attribution License, which permits unrestricted use, distribution, and reproduction in any medium, provided the original work is properly cited. 